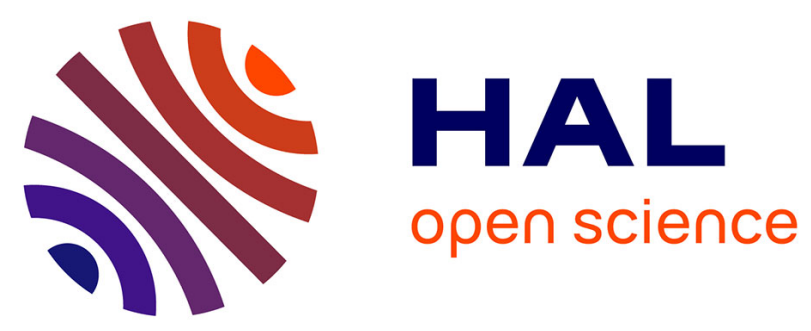

\title{
Designing a Second Generation of Open Data Platforms: Integrating Open Data and Social Media
}

Charalampos Alexopoulos, Anneke Zuiderwijk, Yannis Charapabidis, Euripidis Loukis, Marijn Janssen

\section{- To cite this version:}

Charalampos Alexopoulos, Anneke Zuiderwijk, Yannis Charapabidis, Euripidis Loukis, Marijn Janssen. Designing a Second Generation of Open Data Platforms: Integrating Open Data and Social Media. 13th International Conference on Electronic Government (EGOV), Sep 2014, Dublin, Ireland. pp.230-241, 10.1007/978-3-662-44426-9_19 . hal-01401747

\section{HAL Id: hal-01401747 \\ https://hal.inria.fr/hal-01401747}

Submitted on 23 Nov 2016

HAL is a multi-disciplinary open access archive for the deposit and dissemination of scientific research documents, whether they are published or not. The documents may come from teaching and research institutions in France or abroad, or from public or private research centers.
L'archive ouverte pluridisciplinaire HAL, est destinée au dépôt et à la diffusion de documents scientifiques de niveau recherche, publiés ou non, émanant des établissements d'enseignement et de recherche français ou étrangers, des laboratoires publics ou privés.

\section{(c)(1)}

Distributed under a Creative Commons Attribution| 4.0 International License 


\title{
Designing a second generation of open data platforms: Integrating open data and social media
}

\author{
Charalampos Alexopoulos ${ }^{1}$, Anneke Zuiderwijk ${ }^{2}$, Yannis Charapabidis ${ }^{1}$, \\ Euripidis Loukis ${ }^{1}$, Marijn Yanssen ${ }^{2}$ \\ ${ }^{1}$ Univertity of the Aegean, Dept. Information and Communication Systems Engineering, \\ Samos, Greece \\ \{alexop, yannisx, eloukis\}@ aegean.gr \\ ${ }^{2}$ Delft University of Technology, Faculty of Technology, Policy and Management, \\ Delft, The Netherlands \\ \{a.m.g.zuiderwijk-vaneijk, M.F.W.H.A.Janssen\}@tudelft.nl
}

\begin{abstract}
Two important trends in government that are emerging in the recent years have been on one hand the exploitation of the Web 2.0 social media, supporting a more extensive interaction and collaboration with citizens, and on the other hand the opening of government data to the citizens through the Internet, in order to be used for scientific, commercial and political purposes. However, there has been limited attempt of integrating them. Using a design science approach a second generation of open government data (OGD) platforms has been developed, which offer to the users both the 'classical' first generation functionalities, and also a comprehensive set of additional novel Web 2.0 features. The latter aim to provide support to the users in order to generate value from ODG. They enable users to become 'prosumers', both producing and consuming data. These novel capabilities for performing various types of processing, information and knowledge exchange, and collaboration were found to be useful and valuable by users in a first evaluation.
\end{abstract}

Keywords: open government data, open data, open government, public sector information, e-infrastructures, e-government, Web 2.0, social media, prosumers

\section{$1 \quad$ Introduction}

In the recent years two important technological trends in government have been on the one hand the exploitation of the social media for supporting a more extensive interaction and collaboration with and between persons, and on the other hand the opening of government data to the public, in order to be used for scientific, commercial and political purposes. Both these concepts are associated with the 'open government' concept, which has transparency, public participation, and collaboration as its main components [6]: opening government data is strongly associated with the first one, while social media use is strongly associated with the second and the third. 
Social media have started being used as a tool for increasing citizens' participation in their decision and policy making processes, collecting opinions, knowledge and ideas from citizens, and promoting government transparency and accountability [1-5]. Government - much later than the private sector - attempts to take advantage for the above purposes of the unprecedented capabilities that the new Web 2.0 paradigm provides to simple non-professional users for developing, distributing, accessing, rating and commenting on various types of digital content, and also for the creation of on-line communities. At the same time there is a renewed interest to exploit 'public sector information', by making it available to the citizens and other government agencies (different from its initial creator) through the Internet, in order to be re-used for the generation of both social and economic value [6-12]. Government is one of the largest creators and collectors of data in many different domains. These data might be used for many other purposes, quite different from the ones of their initial creation/collection, e.g. for various scientific, commercial and political purposes.

So far there has been limited attempt to integrate these two developments. As will be explained in more detail in section 2.2, the existing open government data (OGD) platforms provide to their users mainly functionalities for searching and downloading datasets, but limited functionalities for stimulating and facilitating the generation of value from them. This is quite negative taking into account the big investments made by numerous governments for the development and operation of OGD platforms. Literature (e.g. [12-13]) has pointed out that simply opening and publicizing government data will not automatically lead to the generation of social and economic value, and that appropriate stimulation actions have to be taken for this purpose. Therefore it is of critical important to conduct research in order to develop mechanisms for the stimulation and facilitation of value generation from these OGD investments. The underlying premise of our research is that the incorporation of social Web 2.0 functionality in OGD platforms can stimulate value creation by providing networking, interaction and collaboration support among their users. In addition this allows for the consumption and production of content ('pro-sumption') at the same time.

In particular, our paper follows a design science approach in order to develop a second generation of OGD platforms, which offer to the users both the 'classical' first generation functionality, and a comprehensive set of additional novell Web 2.0 oriented functionality aiming to stimulate and facilitate value generation from OGD. This can be very important for the increase of the social and economic value generated from the big investments in OGD platforms. The functionality of such a Web 2.0 OGD platform is described and evaluated using both quantitative and qualitative techniques.

The paper is organized in six sections. In the following section thebackground is presented. Then in section 3 the methodology adopted for the development of this Web 2.0 OGD platform is presented, followed by a description of its functionality in section 4 . The results of the first evaluation are outlined in section 5, while in the final section 6 conclusions are drawn and future research directions are proposed. 


\section{Background}

\subsection{Web 2.0 Social Media Use}

Web 2.0 constitutes a quite different Internet paradigm from its predecessor Web 1.0. It promotes the generation of content of various types by simple and non-expert users, the development of relationships and online communities among them, and the extensive interaction, collaboration and sharing of content and information [14]. A big number of social media platforms have been developed adhering to these characteristics. According to [15] the main capabilities of Web 2.0 social media are:

i) User-generated social content: social media enable users to submit content which other users can access, rate and comment.

ii) Social networking: users of social media join together in online communities, which allow them to see profile information about the people to whom they are connected, and to share information and have extensive interaction with them.

iii) Collaboration: users engage in conversations, co-creation of content, collaborative problem solving, and collective action.

The above capabilities were initially exploited by private sector firms and later started being adopted and utilized by government agencies. Social media can offer government agencies significant opportunities for: i) increasing citizens' participation and engagement in public policy making, by providing to more groups a voice in discussions of policy development, implementation and evaluation; ii) public services co-production, by enabling government agencies and the public to develop and design jointly government services; iii) crowdsourcing solutions and innovations, by exploiting public knowledge and talent in order to develop innovative solutions to the increasingly complex societal problems; iv) promoting transparency-accountability, and in this way reducing corruption, by enabling governments to open up large quantities of activity and spending related data, and at the same time enabling citizens to collectively take part in monitoring the activities of government; v) increasing information and knowledge exchange among government agencies [1-5, 16-20].

\subsection{Opening Government Data}

In the last decade there has been an increase in activities and investments towards opening up of public sector information to the public, in order to be used for scientific, commercial and political purposes [6-12, 21-23]. This information can be valuable for scientific research in many different domains (e.g. in the social, political, economic, administrative and management sciences), and can contribute critically to the development of the 'e-Science' paradigm [9-10]. Furthermore, it can be used by citizens and journalists for gaining better and deeper understanding of and insight into the activities and spending of government agencies. This should result in evidence-based, mature and effective political processes. Also, OGD can have a positive impact on innovation and economic growth, as they enable the development of new applications, products and services. 
Four types of OGD value generation mechanisms are identified in [24-25]: i) efficiency mechanisms (public sector organizations through OGD generate economic value by increasing internal efficiency and effectiveness), ii) transparency mechanisms (public sector organizations generate social value by offering increased transparency into government actions, which reduces 'information 'asymmetry' between government officials and citizens, and therefore misuse of public power for private benefits and corruption), iii) innovation mechanisms (private sector firms generate economic value through the creation of new products and services), iv) participation mechanisms (private sector firms generate social value through participating and collaborating with government).

Many OGD platforms, often in the form of portals, have been developed and operated by government agencies. The existing first generation of OGD digital infrastructures offers mainly basic functionalities for searching and downloading data by the users of these data, and for uploading data by their providers. The majority of these portals offer simple free-text search and theme-browsing functions for the discovery of datasets. Only some portals have recently taken advantage of Semantic Web by providing semantically enriched discovery services, such as performing SPARQL queries. Most OGD platforms limit their data provision services to a simple download functionality, and only a few of them provide functionality to view datasets on a map or various types of charts.

Furthermore, there are no functionalities for processing the datasets in order to improve them, adapt them to specialized needs, or link them to other datasets (public or private), and then for uploading-publishing new versions of them, or for uploading users' own datasets. Furthermore, the 'Linked Data' paradigm is adopted only by some recently developed initiatives, whereas traditional and longstanding public data sources are reluctant to adopt Linked Data andSemantic Web technologies. Also, only a few OGD platforms collect the needs of users for additional datasets in a formal and systematic manner. The majority have only general-purpose feedback web forms for collecting comments and suggestions from users, which typically concern the technical aspects of the platform rather the actual datasets provided. Only some portals include datasets' rating and commenting. Another important weakness are the limitedfunctionalityfor networking, interaction and collaboration among users, in order to generate value from the provided datasets.

In general this first generation of OGD platforms follows mainly the Web 1.0 paradigm, aiming mainly to make OGD available, but do not offer to users functionality supporting the generation of value from them. There is a clear distinction between content producers (public administrations) and content users (research communities, businesses and citizens), and limited interaction and collaboration among them. Our research makes a contribution towards filling the above gaps and overcoming the above weaknesses, through the design of a second generation of OGD platforms, which combine and integrate opening data on one hand, with exploiting the main characteristics of the social media on the other hand, in order to stimulate and facilitate value generation from the OGD. 


\section{Design methodology}

A design science approach was adopted, since "design [...] is concerned with how things ought to be, with devising artefacts to attain goals" [26]. In particular, the Design Science Research Methodology (DSRM) of Peffers et al. [27] was used, consisting of the following six steps:

1. Problem identification and motivation. The problem identified was that little support for creating value of OGD by users is provided, whereas Web 2.0 social media tools can be used for this.

2. Define objectives of a solution. Various sources were used to define the particular objectives of a solution to the above problem, including six semi-structured interviews, a questionnaire and four workshops. The interviews were conducted with open data experts between December 2011 and January 2012. The questionnaire was conducted between April 2012 and September 2012. Both the interviews and the questionnaire provided information about the state of the art of using open public sector data in general, and problems that are experienced in this regard. The questionnaire also asked for activities related to open data use that people would like to conduct, how important and useful they found them. In total 111 people completed the questionnaire. Furthermore, four workshops were conducted at international events to gather information about requirements for a second generation OGD platform. The workshops aimed at engaging various open data users from different countries, so that different types of requirements can be identified. The workshops were conducted between May 2012 and September 2012 and involved 65 participants.

3. Artefact design and development. The previous step of the DSRM led to the design of the Web 2.0 OGD platform, which is described in the following section 4.

4. Artefact demonstration. A first prototype of it was developed and was publicly demonstrated. The platform was presented to open data users at several events (e.g. conference workshops and presentations), and also via Twitter, LinkedIn, Facebook and newsletters.

5. Evaluation. Within an 18-month period, the first prototype of the artefact was evaluated by six groups of students from twoUniversities in the Netherlands and one University in Greece. Since the evaluation concerns a prototype, we were not able to evaluate the whole design of the Web 2.0 OGD platform described in section 4. Evaluations took place in October 2012 ( $n=21$ and $n=33)$, May $2013(n=15)$, September2013 $(n=19)$, October $2013(n=20)$ and November $2013(n=30)$. Most participating students had followed lectures on open data and were familiar with the topic. All evaluations consisted of an online questionnaire, a usability test and a qualitative discussion. In each of the evaluation sessions, the participants were asked to conduct a number of tasks that represented open data use on a Web 2.0 OGD portal. We refer to the whole of these tasks as a usage scenario. More features were added after each iteration of the platform development, based on the evaluation results. The findings of each evaluation were used to further specify the requirements for this new generation of Web 2.0 platforms and to further improve it.

6. Communication of the artefact. The artefact was communicated to potential open 
data users by giving presentations at conferences, organizing workshops, writing publications, sending newsletters to many open data users and using social media.

\section{$4 \quad$ Platform Functionality}

The functionality provided by this advanced OGD platform we developed based on the design methodology presented in the previous section 4 , to the two main stakeholders, the open data users and providers, is shown in Table 1. We focus on its novel Web 2.0 features. It includes a wide set of capabilities for data processing, enhanced data modeling (flat, contextual and detailed metadata), commenting existing datasets and expressing needs for new datasets, datasets quality rating, users groups formation and extensive communication and collaboration within them, data linking, publication/ upload of new versions of existing datasets and advanced data visualization.

Table 1. Novel Web 2.0 Functionalities

\begin{tabular}{|c|c|c|c|}
\hline & Functionality & $\begin{array}{l}\text { Stake- } \\
\text { holder }\end{array}$ & Description \\
\hline 1 & $\begin{array}{l}\text { Data } \\
\text { Processing }\end{array}$ & $\begin{array}{l}\text { Provid- } \\
\text { er/User }\end{array}$ & $\begin{array}{l}\text { (a) data enrichment - i.e. adding new elements - } \\
\text { fields, (b) metadata enrichment - i.e. fill in miss- } \\
\text { ing fields, (c) data cleansing - e.g. detecting and } \\
\text { correcting ubiquities in a dataset, matching text } \\
\text { names to database IDs (keys) etc., (d) converting } \\
\text { datasets other formats, (e) submitting various } \\
\text { types of items - e.g. visualisations, publications - } \\
\text { related to a dataset and (f) datasets combination } \\
\text { and mash-ups. }\end{array}$ \\
\hline 2 & $\begin{array}{l}\text { Data Enhanced } \\
\text { Modeling }\end{array}$ & $\begin{array}{l}\text { Provid- } \\
\text { er/User }\end{array}$ & $\begin{array}{l}\text { description of flat, contextual and detailed meta- } \\
\text { data of any metadata/vocabulary model. }\end{array}$ \\
\hline 3 & $\begin{array}{l}\text { Feedback and } \\
\text { Collaboration }\end{array}$ & $\begin{array}{l}\text { Provid- } \\
\text { er/User }\end{array}$ & $\begin{array}{l}\text { (a) communicate our own thoughts and ideas on } \\
\text { the datasets to the other users and the providers of } \\
\text { them through comments that we can enter on } \\
\text { them, (b) read interesting thoughts and ideas of } \\
\text { other users on the datasets through comments } \\
\text { entered on them, (c) express our own needs for } \\
\text { additional datasets that would be interesting and } \\
\text { useful to us, (d) get informed about the needs of } \\
\text { other users for additional datasets and (e) get } \\
\text { informed about datasets extensions and revisions. }\end{array}$ \\
\hline 4 & $\begin{array}{l}\text { Data Quality } \\
\text { Rating }\end{array}$ & User & $\begin{array}{l}\text { (a) communicate to the other users and the pro- } \\
\text { viders the level of quality of the datasets we } \\
\text { perceive, (b) get informed on the level of quality } \\
\text { of the datasets perceived by other users through }\end{array}$ \\
\hline
\end{tabular}




\begin{tabular}{|c|c|c|c|}
\hline \multicolumn{4}{|r|}{ their ratings. } \\
\hline 5 & $\begin{array}{l}\text { Grouping and } \\
\text { Interaction }\end{array}$ & $\begin{array}{l}\text { Provid- } \\
\text { er/User }\end{array}$ & $\begin{array}{l}\text { (a) searching for and finding other users- } \\
\text { providers having similar interests with us, in order } \\
\text { to have information and knowledge exchange and } \\
\text { cooperation with them, (b) forming groups with } \\
\text { other users-providers having similar interests with } \\
\text { us in order to have information and knowledge } \\
\text { exchange and cooperation with them, (c) main- } \\
\text { taining datasets/working on datasets within one } \\
\text { group, (d) communicating with other us- } \\
\text { ers/providers through messages in order to ex- } \\
\text { change information and knowledge, (e) getting } \\
\text { immediately updated about the upload of new } \\
\text { versions and enrichments of datasets main- } \\
\text { tained/worked on within the group, or new rele- } \\
\text { vant items (e.g. publications, visualizations, etc.). }\end{array}$ \\
\hline 6 & Data Linking & $\begin{array}{l}\text { Provid- } \\
\text { er/User }\end{array}$ & $\begin{array}{l}\text { (a) Data and metadata linking toother ontologies } \\
\text { in the Linked Open Data Cloud, (b) Capabilities } \\
\text { of querying data and metadata through Sparql } \\
\text { Endpoints. }\end{array}$ \\
\hline 7 & $\begin{array}{l}\text { DataVersions } \\
\text { Publica- } \\
\text { tion/upload }\end{array}$ & $\begin{array}{l}\text { Provid- } \\
\text { er/User }\end{array}$ & $\begin{array}{l}\text { Support for publication/upload of new versions of } \\
\text { the existing datasets, and connection with pre- } \\
\text { vious ones and initial datasets. }\end{array}$ \\
\hline 8 & $\begin{array}{l}\text { Data Visualiza- } \\
\text { tion }\end{array}$ & User & $\begin{array}{l}\text { Advanced datasets' visualization capabilities } \\
\text { (maps, charts, plots and other) }\end{array}$ \\
\hline
\end{tabular}

\section{$5 \quad$ Evaluation}

We proceeded next to the evaluation of this advanced second generation OGD platform. The evaluation covered both its classical and novel features, but in this paper we report on the latter, as they are our main focus.

The quantitative part of the evaluation included the design of a questionnaire, which was distributed to users of the OGD platform (who implemented some usage scenarios of it, acting both as data users and providers). All these questions have the form of positive statements, and the users were asked to enter the extent of their agreement or disagreement with these statement by answering the question: "To which extend do you agree with the following statements?". A five point Likert scale was used to measure agreement or disagreement with (i.e. positive or negative response to) such a statement (1=Strongly Disagree, 2= Disagree, 3=Neutral, 4=Agree, 5=Strongly Agree). Table 2 lists the questions, and the corresponding average rating results. All of them are between 3 (neutral) and 4 (agreement to the positive statement), which 
indicates a positive attitude of the users towards this novel functionality. The highest ratings are for the feedback and collaboration capabilities allowing the exchange of comments on existing datasets and needs for new datasets. Given that a prototype was used in this evaluation, and a complete platform can perform even better, these results give a clear indication that users value these web 2.0 social web features.

Table 2. Questions and results concerning Web 2.0 features

\begin{tabular}{lc}
\hline Functionalities & $\begin{array}{c}\text { Average } \\
\text { Ratings }\end{array}$ \\
\hline Data Processing & $\mathbf{3 , 3 4}$ \\
\hline $\begin{array}{l}\text { The platform provides good capabilities for data enrichment (i.e. adding } \\
\text { new elements - fields). }\end{array}$ & 3,43 \\
$\begin{array}{l}\text { The platform provides good capabilities for metadata enrichment (i.e. } \\
\text { fill in missing fields). }\end{array}$ & 3,42 \\
$\begin{array}{l}\text { The platform provides good capabilities for data cleansing (e.g. detect- } \\
\text { ing and correcting ubiquities in a dataset, matching text names to data- } \\
\text { base IDs (keys) etc.). }\end{array}$ & 3,41 \\
$\begin{array}{l}\text { The platform provides good capabilities for converting datasets to } \\
\text { another format. }\end{array}$ & 3,39 \\
$\begin{array}{l}\text { The platform provides good capabilities for linking datasets (including } \\
\text { linking RDF files to LOD cloud). }\end{array}$ & 3,40 \\
$\begin{array}{l}\text { The platform provides good capabilities for submitting various types of } \\
\text { items (e.g. visualisations, publications) related to a dataset. }\end{array}$ & 3,43 \\
$\begin{array}{l}\text { The platform provides good capabilities for datasets combination/ } \\
\text { Mash-ups. }\end{array}$ & 3,42 \\
\hline $\begin{array}{l}\text { Feedback and Collaboration } \\
\text { The platform enables me to read interesting thoughts and ideas of other } \\
\text { users on the datasets through the comments they enter on them. }\end{array}$ & 3,64 \\
$\begin{array}{l}\text { The platform enables me to communicate my own thoughts and ideas } \\
\text { on the datasets to the other users and the providers of them through } \\
\text { comments I enter. }\end{array}$ & 3,62 \\
$\begin{array}{l}\text { The platform enables me to express my needs for additional datasets } \\
\text { that would be interesting and useful to me. } \\
\begin{array}{l}\text { The platform enables me to get informed about the needs of other users } \\
\text { for additional datasets. }\end{array}\end{array}$ & 3,62 \\
$\begin{array}{l}\text { The platform enables me to read interesting thoughts and ideas of the } \\
\text { users on the datasets and the extensions I have uploaded by reading the } \\
\text { comments they entered on them. }\end{array}$ & 3,59 \\
\hline & \\
\hline
\end{tabular}


The platform enables me to get informed on the level of quality of the datasets and the extensions I have uploaded that is perceived by the users of them by reading their ratings.

The platform enables me to get informed about the needs of the users of the datasets and the extensions I have uploaded for additional ones.

Data Quality Rating

The platform enables me to get informed on the level of quality of the datasets perceived by other users through their ratings

The platform enables me to communicate to the other users and the providers the level of quality of the datasets that I perceive

\begin{tabular}{lc}
\hline Grouping and Interaction & $\mathbf{3 , 4 7}$ \\
\hline $\begin{array}{l}\text { The platform enables searching for and finding other users having simi- } \\
\text { lar interests with me in order to have information and knowledge ex- } \\
\text { change and cooperation }\end{array}$ & 3,48 \\
\hline $\begin{array}{l}\text { The platform enables forming groups with other users having similar } \\
\text { interests with me in order to have information and knowledge exchange } \\
\text { and cooperation }\end{array}$ & 3,47 \\
\hline $\begin{array}{l}\text { The platform enables maintaining datasets/working on datasets within } \\
\text { one group }\end{array}$ & 3,47 \\
\hline $\begin{array}{l}\text { The platform enables communicating with other users through messages } \\
\text { in order to exchange information and knowledge }\end{array}$ & 3,46 \\
\hline $\begin{array}{l}\text { The platform enables getting immediately updated about the upload of } \\
\text { new versions and enrichments of datasets maintained/worked on within } \\
\text { the group, or new relevant items (e.g. publications, visualizations, etc.) }\end{array}$ & 3,45 \\
\hline
\end{tabular}

From the qualitative discussions that were organized in each of the evaluation sessions it became clear that the novel Web 2.0 features of the OGD platform were evaluated positively by the participants. For instance, one of the participants of the third evaluation session said that the prototype was quite valuable because it "stimulates exchange of information and improvement of datasets". In the same evaluation session it was also pointed out that it is "easy to add comments" and that "the rating system for datasets is useful". A participant in the next evaluation session said that "the quality rating system is nice" and another participant stated: "I like the idea that you can make a request for a dataset. If you cannot find it yourself, the community will help you". In the fifth and sixth evaluation sessions the participants were also very positive about the data request feature. It was mentioned that "nice that you can see whether a request has been satisfied" and "I like the idea that the community will help you find a dataset making only a request for it". Despite that there were several difficulties with the use of this prototype (e.g. difficulties with visualizations of dataset and the response times), the participants stated that overall it was easy to use. 
The participants of the discussions also stated that there were various areas for improvement of the prototype. One important area concerns the limited amount of users at that time, so more users are necessary to create a network effects. It was commented "the platform is only useful when you have many users", and "very little feedback provided up until now". One participant described that there is some uncertainty about whether the extended or added datasets by users (and not by government agencies) are correct and reliable. Another participant stated that a useful additional feature for addressing this issue could be to enable users to rate other users, and users to obtain credits when they conduct 'positive' activities, such as uploading interesting datasets. This can lead to the development of a users' reputation mechanism.

Furthermore, the participants stated that the prototype could be improved by: a) improving search capabilities of the list of people registered on the OGD platform, b) enhancing group creation capabilities, c) enabling sending private message to another user, d) having a better Wiki-like layout, e) making the rating system more clearly visible and f) by showing the number of replies on a data request on top of the page. All the above comments and suggestions of the users were taken into account for the development of a new version of the platform.

\section{Conclusions}

Government agencies are increasingly interested in opening their data, in order to be used for scientific, political or commercial purposes (i.e. development of new value added services/applications). This has led to big investments for the development and operation of a first generation of OGD platforms. These platforms offer mainly capabilities for searching and downloading datasets, but limited capabilities for stimulating and facilitating the generation of value from them. Using a design science approach a second generation of Web 2.0 OGD platforms has been developed, offering to the users both the 'classical' first generation capabilities, and also a comprehensive set of additional Web 2.0 social media oriented capabilities. A first evaluation of this new concept shows that users appreciate these novel social Web 2.0 oriented features, and find them useful and valuable. So we have some first evidence that the proposed integration of these two major technological trends observed in government in the recent years, social media and data opening, can be succesful and beneficial.

Our research has interesting implications for research and practice. It opens up a new stream of research towards the enhancement of the classical OGD platform with novell features supporting data 'pro-sumption' and also interaction and collaboration with other users and government agencies, which can benefit from the extensive research that has been conducted in the computer supported collaborative work and communities' of practice domains. Furthermore, OGD practice should move from the simple provision of data to the support and facilitation of their exploitation and value generation from them, using both technological and organizational instruments. Further research is required in this direction, including the development of more advanced versions of this OGD platform, and its further evaluation by different groups 
of 'more professional' users (than the students who have participated in these first evaluations), such as researchers, journalists, politicians, value added services and application developers.

Acknowledgements. The research presented in this paper has been conducted as part of the ENGAGE FP7 Infrastructure Project (its full title is 'An Infrastructure for Open, Linked Governmental Data Provision Towards Research Communities and Citizens' - see http://www.engage-project.eu/wp/)

\section{References}

1. Bertot, J. C., Jaeger, P. T., Grimes J. M.: Promoting transparency and accountability through ICTs, social media, and collaborative e-government. Transforming Government: People, Process and Policy 6(1), 78 - 91 (2012)

2. Bonsón, E., Torres, L., Royo, S., Flores, F.: Local e-government 2.0: Social media and corporate transparency in municipalities. Government Information Quarterly 29, 123-132 (2012)

3. Chun, S. A. and Luna Reyes, L. F.: Editorial - Social media in government. Government Information Quarterly 29, 441-445 (2012)

4. Margo, M. J.: A Review of Social Media Use in E-Government. Administrative Sciences, Administrative Sciences 2(2), 148-161 (2012)

5. Criado, J. I., Sandoval-Almazan, R., Gil-Garcia, J. R.: Government innovation through social media. Government Information Quarterly 30, 319-326 (2013)

6. McDermott, P.: Building open government. Government Information Quarterly 27(4), 401-413 (2010)

7. Janssen, K.: The influence of the PSI directive on open government data: An overview of recent developments. Government Information Quarterly 28, 446-456 (2011)

8. Kundra, V.: Digital Fuel of the 21st Century: Innovation through Open Data and the Network Effect. Joan Shorenstein Center on the Press, Politics and Public Policy, Harvard, MA (2012)

9. Commission of the European Communities: Communication fromthe Commissionto the European Parliament, the Council and the European Economic and Social Committee on scientific information in the digital age: access, dissemination and preservation. COM (2007) 56 Final, Brussels (2007)

10. Commission of the European Communities: Communication from the Commission to the European Parliament, the Council, the European Economic and Social Committee and the Committee of the Regions - ICT Infrastructures for e-Science. COM (2009) 108 Final, Brussels (2009)

11. Luna-Reyes, L. F., Bertot, J. C., Mellouli, S.: Editorial - Open Government, Open Data and Digital Government. Government Information Quarterly 31, 4-5 (2014)

12. Zuiderwijk, A., Janssen, M.: Open data policies, their implementation and impact: A framework for comparison. Government Information Quarterly, 31, 17-29 (2014) 
13. Janssen, M., Charalabidis, Y., Zuiderwijk, A.: Benefits, adoption barriers and myths of Open Data and Open Government. Information Systems Management 29(4), 258-268 (2012)

14. O'Reilly, T.: What is Web 2.0: Design patterns and business models for the next generation of software. Communications and Strategies 1, 17-37 (2007)

15. Davis, T., Mintz, M.: Design features for the social web: The Arcquitecture of Deme. In: Proceedings of 8th International Workshop on Web-Oriented Software Technologies IWWOST (2009)

16. Bovaird, T.: Beyond engagement and participation: User and community coproduction of public services. Public Administration Review 67(5), 846-860 (2007)

17. Torres, L. H.: Citizen sourcing in the public interest. Knowledge Management for Development Journal 3(1), 134-145 (2007)

18. Lukensmeyer, C. J., Torres, L. H.: Citizensourcing: Citizen participation in a networked nation. In: K. Yang, \& E. Bergrud (Eds.) Civic engagement in a network society, pp. 207233. Information Age Publishing, Charlotte, NC (2008)

19. Bertot, J. C., Jaeger, P. T., Grimes J. M.: Promoting transparency and accountability through ICTs, social media, and collaborative e-government. Transforming Government: People, Process and Policy 6(1), 78 - 91 (2012)

20. Linders, D.: From e-government to we-government: Defining a typology for citizen coproduction in the age of social media. Government Information Quarterly 29, 446-454 (2012)

21. Dekkers, M., Polman, F., De Velde, R., De Vries, M.: MEPSIR - Measuring European Public Sector Information Resources: Final report of study on exploitation of public sector information - benchmarking of EU framework Conditions. Report for the European Commission, Brussels (2006)

22. European Union: Directive 2003/98/EC of the European Parliament and of the Council of 17 November 2003 on the re-use of public sector information. Official Journal of the European Union, Luxembourg (2003)

23. Commission of the European Communities: Communication from the Commission to the European Parliament, the Council, the European Economic and Social Committee and the Committee of the Regions - Open data: An engine for innovation, growth and transparent governance. COM (2011) 882 Final, Brussels (2011)

24. Jetzek, T., Avital, M., Bjorn-Andersen, N.: The Value of Open Government Data: A Strategic Analysis Framework. In: Proceedings of SIG eGovernment pre-ICIS Workshop, Orlando, USA (2012)

25. Jetzek, T., Avital, M., Bjorn-Andersen, N.: The Generative Mechanismsof Open Government Data. In: Proceedings of of the 21st European Conference on Information Systems (ECIS), Utrecht, The Netherlands (2013)

26. Simon, H. A.: The Sciences of the Artificial - 3rd edition. MIT Press, MA (1996)

27. Peffers, K., Tunanen, T., Rothenberger, M. A., Chatterjee, S.: A Design Science Research Methodology for Information Systems Research. Journal of Management Information Systems 24, 45-77 (2008). 